\title{
Nitric Oxide and Carbon Monoxide Activate Locus Coeruleus Neurons through a cGMP-Dependent Protein Kinase: Involvement of a Nonselective Cationic Channel
}

\author{
Joseba Pineda, ${ }^{1}$ Jeffrey H. Kogan, ${ }^{2}$ and George K. Aghajanian ${ }^{1,3}$ \\ Departments of ${ }^{1}$ Psychiatry, ${ }^{2}$ Cellular and Molecular Physiology, and ${ }^{3 P h a r m a c o l o g y, ~ Y a l e ~ I n i v e r s i t y ~ S c h o o l ~ o f ~ M e d i c i n e ~}$ \\ and the Ribicoff Research Facilities, Connecticut Mental Health Center, New Haven, Connecticut 06508
}

Nitric oxide $(\mathrm{NO})$ and carbon monoxide $(\mathrm{CO})$ have been identified as two diffusible signaling messengers in the brain, capable of stimulating soluble guanylate cyclase. Locus coeruleus (LC) is rich in the $\alpha_{1}$ and $\beta_{1}$ subunits of soluble guanylate cyclase. Therefore, the possible role of the cGMP pathway in the regulation of $L C$ neurons was investigated with electrophysiological techniques in rat brain slices. Bath application of various NO donors or CO-containing solutions increased the firing rate of most LC neurons. This activation was reversed by the NO scavenger hemoglobin, but not by methemoglobin. Bath or intracellular application of selective activators of cGMPdependent protein kinase also caused increases in LC cell firing rate. The actions of NO donors and kinase activators were mutually occlusive and reversed by $\mathrm{H} 8$, an inhibitor of the cGMP-dependent protein kinase. Hemoglobin and $\mathrm{H} 8$ reduced the firing rate of $L C$ neurons, but no change was found with inhibitors or activators of the NO synthase. In intracellular and whole-cell recordings, NO effect was associated with an inward current and an increase in the input conductance (mean reversal potential $=-27 \mathrm{mV}$ ); these effects were abolished using a low-sodium buffer. Spontaneous EPSCs of LC cells were not modified with the NO donor administration. Taken together, these data suggest that $\mathrm{NO}$ and $\mathrm{CO}$ activate noradrenergic neurons of LC via a cGMP-dependent protein kinase and a nonselective cationic channel. It also is proposed that these effects occur at the postsynaptic level and that there may be a tonic regulation of $L C$ neuronal firing by the CGMP pathway.

Key words: nitric oxide; carbon monoxide; CGMP; CAMP; protein kinases; locus coeruleus; noradrenergic; nonselective cationic channel; intracellular; brain slices
Recent evidence has suggested that nitric oxide (NO) and carbon monoxide (CO), two small gaseous molecules, can function as intercellular signaling messengers in the brain (for review, see Dawson and Snyder, 1994; Vincent, 1994). NO first was reported to mediate the NMDA-induced increase in cGMP in cerebellar granule cells (Garthwaite et al., 1988). Subsequently, NO has been implicated in a wide range of physiological roles within the CNS (Bruhwyler et al., 1993). In neurons, NO is derived from L-arginine by a $\mathrm{Ca}^{2+} /$ calmodulin-activated NO synthase (NOS) (Knowles and Moncada, 1994): This enzyme is distributed widely throughout the brain (Bredt et al., 1991; Snyder and Bredt, 1991; Vincent and Kimura, 1992). More recently, CO has emerged as another possible diffusible messenger in the CNS (Marks et al., 1991; Stevens and Wang, 1993; Zhuo et al., 1993). The enzyme responsible for $\mathrm{CO}$ formation, the noninducible heme oxygenase (HO), also is localized in restricted areas of the brain (Maines, 1993; Verma et al., 1993). In many systems, NO and CO exert their biological effects by activating the soluble isoform of guanylate cyclase to raise the intracellular concentration of cGMP (Arnold et al., 1977; Verma et al., 1993). Specific targets for this pathway are cGMP-dependent protein kinases (PaupardinTritsch et al., 1986), cGMP-gated cationic channels (Fesenko et

Received Sept. 28, 1995; revised Nov. 29, 1995; accepted Dec. 1, 1995.

This work was supported in part by National Institute on Drug Abuse Program Projects Grant 5-P01-DA08227.J.P. was supported by a postdoctoral fellowship from Gobicrno Vasco. Wc thank Ms. N. Margiotta for technical assistance.

Correspondence should be addressed to George K. Aghajanian, Department of Psychiatry, CMHC 306, Yale University School of Medicine, 34 Park Street, New Haven, CT 06508.

Copyright $(\mathcal{O} 1996$ Society for Neuroscience $0270-6474 / 96 / 161389-11 \$ 05.00 / 0$ al., 1985), and cGMP-stimulated and -inhibited phosphodiesterases (Nicholson et al., 1991).

It has been proposed that cAMP plays an important role in the physiology of locus coeruleus (LC) neurons (Wang and Aghajanian, 1987, 1990; Alreja and Aghajanian, 1991): agents that either elevate intracellular levels of cAMP or mimic cAMP effects increase LC cell firing rate by inducing a nonselective cationic inward current via the cAMP-dependent protein phosphorylation pathway. In contrast, only indirect observations have been reported about the physiological significance of cGMP in LC neurons. First, in situ hybridization studies have shown a high density of $\alpha_{1}$ and $\beta_{1}$ subunits of soluble guanylate cyclase in LC (Matsuoka et al., 1992; Furuyama et al., 1993). Second, immunohistochemical experiments have revealed the presence of NOS-positive neurons and processes within and close to the LC (Xu et al., 1994). Third, intracellular recordings have shown the ability of NO to modulate excitatory inputs to noradrenergic neurons in the LC (Xu et al., 1994).

This study was conducted with extracellular, intracellular, and whole-cell recording techniques to characterize pharmacologically and physiologically the role of cGMP pathway in the regulation of LC activity in rat brain slices. For this purpose, we examined the effects of various $\mathrm{NO}$ donors and $\mathrm{CO}$ on $\mathrm{LC}$ firing rates. The possible involvement of a protein kinase pathway and the interaction between cGMP and cAMP systems were analyzed. Whether the endogenous synthesis of NO itself might contribute to regulation of this pathway also was evaluated. Finally, the ionic mechanism by which such regulation by $\mathrm{NO}$ or $\mathrm{CO}$ might occur was studied. 


\section{MATERIALS AND METHODS}

LC slices were prepared from adult male albino rats $(150-200 \mathrm{gm}$, Camm, Wayne, NJ) as described previously (Wang and Aghajanian, 1987). Coronal sections $(600 \mu \mathrm{m})$ of brainstem containing the LC were cut with a vibrating-knife microtome (Vibraslice, World Precision Instruments, Sarasota, FL). Slices were then incubated at $33 \pm 0.5^{\circ} \mathrm{C}$ in an interface chamber continuously perfused with artificial CSF (aCSF) at an approximate rate of $1 \mathrm{ml} / \mathrm{min}$. The aCSF was composed of (in $\mathrm{mM}$ ): $\mathrm{NaCl}$ $128, \mathrm{KCl} 3, \mathrm{NaH}_{2} \mathrm{PO}_{4} 1.25$, D-glucose $10, \mathrm{NaHCO}_{3} 25, \mathrm{CaCl}_{2} 2$, and $\mathrm{MgSO}_{4} 2$, and equilibrated with $95 \% \mathrm{O}_{2} / 5 \% \quad \mathrm{CO}_{2}, \mathrm{pH} \sim 7.34$. 'lest substances were added by perfusion in the bathing medium by switching to a drug-containing solution using a system of manually controlled three-way valves. The LCs were identified visually in the rostral pons as dark oval areas on the lateral borders of the central gray and IVth ventricle at a frontal plane at or just anterior to the genu of facial nerve.

Single-unit extracellular recordings were performed with glass micropipettes filled with $2 \mathrm{M} \mathrm{NaCl}(4-8 \mathrm{M} \Omega$ ). Input voltage was amplified with a high-input impedance amplifier ( $\Lambda$ xoclamp $2 \Lambda$, $\Lambda$ xon Instruments, Foster City, CA) and monitored on an audioamplifier and an oscilloscope. Firing rates were obtained by a window discriminator and continually collected before, during, and after drug applications on a pen chart recorder as integrated time histograms ( $10 \mathrm{sec}$ reset time). Noradrenergic neurons in the LC were identified by the characteristic triphasic waveforms and by the spontaneous firings at a regular and slow rhythm $(\sim 1$ $\mathrm{Hz}$ ) (Andrade et al., 1983).

Intracellular recordings were conducted using the discontinuous singleelectrode voltage-clamp mode of an Axoclamp 2A amplifier. Sharp microelectrodes $(-8 \mathrm{~mm}$, shank to tip) with relatively low capacitance and resistance $(25-35 \mathrm{M} \Omega$ ) were pulled from $1.5 \mathrm{~mm}$ filament-containing capillary tubing with a Brown-Flaming electrode puller (Sutter Instruments, Novato, CA) and filled with $2 \mathrm{M} \mathrm{KCl}$. Electrodes prepared in this manner had rapid settling times $(50-75 \mu \mathrm{sec})$, which allowed voltageclamp switching frequencies of $4-6 \mathrm{kHz}$ and a loop gain of $10 \mathrm{nA} / \mathrm{mV}$ ( $30 \%$ duty cycle). The amplifier output was monitored on an oscilloscope and an audioamplifier; the series resistance was checked using a bridge current. During the experiment, the headstage voltage was monitored visually with a separate oscilloscope to ensure that the voltage transients across the microelectrode decayed fully before sampling voltage. Phase lag was used to prevent oscillations. False clamping was avoided by using optimal capacitance compensation and by selecting the switching frequency that settled the input voltage to a horizontal baseline. Cells were voltage clamped at $-60 \mathrm{mV}$ and the current responses were collected continually before and during drug applications on a pen chart recorder. Current-voltage plots ( $I-V$ curves) were obtained in each experimental condition using slow ramps $(6 \mathrm{mV} / \mathrm{sec})$ generated by pClamp software (version 6.0.2, Axon Instruments) on a PC-based computer. Data were digitized via DigiData 1200 Interface (Axon Instruments) passed through CyberAmp 320 Signal Conditioner (Axon Instruments) with a $10 \mathrm{~Hz}$ low-pass filter cutoff frequency, and then acquired, stored, and plotted using pClamp. LC neurons were characterized by the high-input resistances (50-200 M $\Omega$ ), the large afterhyperpolarizations, and the longduration action potentials ( $\sim 2 \mathrm{msec}$ ) (Wang and Aghajanian, 1987). The cells selected for this study had spike amplitudes $>75 \mathrm{mV}$ and firing rates $<4 \mathrm{~Hz}$.

Whole-cell recordings were performed with an Axoclamp 2A amplifier and patch microelectrodes (2-3 M $\Omega$ ) containing (in $\mathrm{mM}$ ): $\mathrm{K}$ gluconate 120, HEPES 10 , BAPTA $\mathrm{K}_{4} 5$, sucrose $20, \mathrm{CaCl}_{2} 2.38, \mathrm{MgCl}_{2}, 1, \mathrm{~K}_{2}$ ATP 1 , and GTP $0.1(\mathrm{pH} \sim 7.35)$. A gentle suction applied to the patch pipette formed a giga-seal with the cell membrane (cell-attached mode), and then an additional pulse of suction established the full-access mode. Pipette access to the cell's interior was monitored continually through the bridge circuit by recording the instantaneous voltage responses to $200 \mathrm{pA} \times 200$ msec pulses. To study the effect of intracellular application of 8 -Br-cGMP or 8-pCPT-cGMP on the firing rate, the nucleotide was added to the control pipette solution at the desired concentration, and the basal firing rates were obtained in the cell-attached mode and then compared with those after the full access was reached. When the full access is achieved there is a rapid diffusion of small molecules from the electrode (Alreja and Aghajanian, 1991). Postsynaptic currents (PSCs) were studied in the continuous single-electrode voltage-clamp mode; a $3000 \mathrm{~Hz}$ low-pass filter cutoff frequency was used in these experiments. PSCs were sampled by 10 successive episodes ( $1 \mathrm{sec}$ duration each) during baseline and drug application using pClamp software.

Except when otherwise mentioned, all effects on firing rales are referred to as the percentage change from the mean basal rate when the maximal effect of each concentration was achieved. In some cases, cumulative concentration-response curves were constructed using the nonlinear least-squares fitting program GraphPad Prism (version 1.0, GraphPad Software, San Diego, CA) (Motulsky and Ransnas, 1987). In each experiment, data were analyzed for the best simple fit to the threeparameter logistic equation (De Lean et al., 1978): $E=E_{\text {max }} /(1+$ $\left.\left(\mathrm{EC}_{50} /[D]\right)^{\mathrm{n}}\right)$, where $[D]$ is the concentration of the drug, $E$ is the change in the firing rate induced by $D, E_{\max }$ is the maximal change at "infinite" concentration, $\mathrm{EC}_{50}$ is the effective concentration for eliciting $50 \%$ of $E_{\max }$, and $n$ is the slope factor of the function. $E_{\max }, \mathrm{EC}_{50}$, and $n$ were calculated by the fitting program. Values are expressed as mean \pm SEM. Statistical significances were evaluated using two-tailed paired Student's $t$ test for comparisons of firing rates before and after drugs, and two-tailed two-sample Student's $t$ test for comparisons of independent groups. The level of significance was considered as $p=0.05$.

Sodium substitution in the aCSF was performed by replacing $80 \%$ of the $\mathrm{NaCl}$ equiosmolarly with trizma hydrochloride/base (Tris). L-Arginine, 8-Br-cAMP, cGMP, hemoglobin ( $\mathrm{Hb}$, bovine), methemoglobin (MetHb, bovine), sodium nitroprusside (SNP), and TTX were purchased from Sigma (St. Louis, MO). 8-Br-cGMP, N ${ }^{G}$-monomethyl-Larginine acetate (NMMA), $\mathrm{N}^{\mathrm{G}}$-nitro-L-arginine methyl ester (L-NAME), 7-nitroindazole (7-NI), and S-nitroso-N-acetylpenicillamine (SNAP) were purchased from Research Biochemicals (Natick, MA). 3-Morpholinosydnonimine (SIN-1) was from Calbiochem (San Diego, CA). $\mathrm{N}$-[2-(Methylamino)ethyl]-isoquinolinesulfonamide $(\mathrm{H} 8)$ was from LC Labs (Woburn, MA). 8-(p-Chlorophenylthio)-cGMP (8-pCPTcGMP) was from BioLog (La Jolla, CA). 1,1-Dicthyl-2-hydroxy-2nitrosohydrazine (diethylamine NONOate or DEA-NONOate) was from Cayman Chemical (Ann Arbor, MI). SNAP was first dissolved in pure dimethyl sulfoxide (DMSO) and then diluted in aCSF to obtain a final concentration of $0.1 \%$ DMSO. It has been shown previously that $0.1 \%$ DMSO does not have any discernible effect on LC cell firing rate (Wang and Aghajanian, 1987). DEA-NONOate was stored in dilute $\mathrm{NaOH}$ (10 $\mathrm{mM}, \mathrm{pH}=12)$ to prevent the spontaneous release of NO; just before its application it was dissolved in a small volume of acidic aCSF, $\mathrm{pH}=5$, to initiate the release of NO, and then diluted 1000- to 10,000 -fold in standard aCSF for immediate use at the desired concentration and final $\mathrm{pH}$ of 7.34. Other drugs were dissolved directly in aCSF at known concentrations. All solutions were made freshly before each experiment, except $\mathrm{H} 8$ and TTX, which were kept at $4^{\circ} \mathrm{C}$ as $10 \mathrm{~mm}$ and $150 \mu \mathrm{M}$ stock solutions, respectively.

\section{RESULTS}

\section{Effect of NO donors on LC firing rate}

The effect of bath applications of four different NO donors (SNP, SNAP, SIN-1, and DEA-NONOate) on the firing rates of LC cells was studied using extracellular recordings. In 32 of 36 cells, SNP ( $1 \mathrm{~mm}$ ) produced a clear increase in the LC cell firing rate. In the responsive cells, the maximal activation (Table 1 ) was reached at 4-8 min and did not reverse within 15-20 min of washout (Fig. $1 A$ ). Lower concentrations of SNP revealed that the SNP effect was concentration-dependent. Hence, cumulative concentrationresponse curves were performed by increasing SNP concentration $(10 \mu \mathrm{M}$ to $3 \mathrm{~mm}, 3.3 \times$ ) at intervals of $\sim 10 \mathrm{~min}$ after each successive application until a maximal response was obtained; the maximal effect estimated by the fitting program was $185 \pm 41 \%$ over basal, and the $\mathrm{EC}_{50}$ was $334 \pm 86 \mu \mathrm{M}(n=5$; Fig. 2$)$. Potassium ferricyanide (1 $\mathrm{mm}$ ), a structural analog of SNP without NO donating properties, failed to change the firing rate in the same cell in which SNP increased the rate (Fig. $1 B$ ). The bath application of the structurally unrelated NO donors SNAP, SIN-1, or DEA-NONOate also promoted activations of LC cells in a concentration-dependent manner. The magnitude of responses to these NO donors is shown in Table 1. The time course for the onset and the peak of these effects was similar to that seen with SNP. In contrast to SNP, a complete (SNAP and DEANONOate) or partial (SIN-1) recovery of the activation was observed during a short-term washout of the drugs (Fig. 1C-E). The rapid recovery observed during DEA-NONOate administra- 
Table 1. Effect of various drugs related with cGMP pathway on the firing rate of $L C$ neurons in rat brain slices

\begin{tabular}{lccc} 
Drug (concentration) & $\begin{array}{l}\text { Basal firing } \\
\text { rate }(\mathrm{sp} / 10 \\
\text { sec) }\end{array}$ & $\begin{array}{l}\text { Percentage } \\
\text { change from } \\
\text { basal firing rate }\end{array}$ & $\begin{array}{c}\text { Responsive/ } \\
\text { tested cells }\end{array}$ \\
\hline SNP $(1 \mathrm{~mm})$ & $6.0 \pm 0.4$ & $+112 \pm 20^{* * *}$ & $32 / 36$ \\
SNAP (3 mM) & $5.7 \pm 1.0$ & $+68 \pm 11^{*}$ & $5 / 6$ \\
SIN-1 (1 mM) & $6.2 \pm 0.8$ & $+73 \pm 9^{* * *}$ & $7 / 10$ \\
DEA-NONOate $(50 \mu \mathrm{M})$ & $5.1 \pm 2.6$ & $+104 \pm 10^{* *}$ & $7 / 7$ \\
8-Br-cGMP $(1 \mathrm{mM})$ & $6.5 \pm 0.9$ & $+102 \pm 18^{* * *}$ & $14 / 20$ \\
8-pCPT-cGMP & & & \\
$\quad(200-400 \mu \mathrm{M})$ & $5.4 \pm 1.2$ & $+73 \pm 19^{* *}$ & $4 / 6$ \\
8-Br-cAMP $(2 \mathrm{mM})$ & $7.8 \pm 0.9$ & $+124 \pm 23^{* *}$ & $6 / 6$ \\
H8 $(100 \mu \mathrm{M})$ & $8.0 \pm 1.6$ & $-37 \pm 5^{* *}$ & $8 / 9$ \\
Hb $(100 \mu \mathrm{M})$ & $7.0 \pm 0.5$ & $-77 \pm 4^{* * *}$ & $31 / 32$ \\
MetHb $(100 \mu \mathrm{M})$ & $5.3 \pm 0.8$ & - & $0 / 8$ \\
L-Arginine $(0.3-1 \mathrm{mM})$ & $8.0 \pm 1.1$ & - & $0 / 6$ \\
L-NAME $(100-300 \mu \mathrm{M})$ & $8.4 \pm 1.5$ & - & $0 / 8$ \\
NMMA $(100 \mu \mathrm{M})$ & $5.6 \pm 0.1$ & - & $0 / 2$ \\
7-NI $(100 \mu \mathrm{M})$ & $12.0 \pm 2.0$ & $+22 \pm 3^{*}$ & $2 / 2$ \\
CO (saturated) & $6.7 \pm 0.6$ & $+80 \pm 16^{* * *}$ & $23 / 29$ \\
\hline Agts & & &
\end{tabular}

Agents were applied in the perfusion bathing the slice.

"Basal $=0 \%$; "+" and "-" are increases or decreases, respectively. Values are means \pm SEM of the responsive cells. Means \pm SEM of all tested cells for MetHb, L-arginine, L-NAME, and NMMA are $11 \pm 8,-1 \pm 8,-2 \pm 5$, and $-4 \pm 4 \%$, respectively.

${ }^{*} p<0.05 ;{ }^{* *} p<0.01 ;{ }^{* *} p<0.001$ when firing rates before versus after the drug are compared by a two-tailed, paired Student's $t$ test.

tion was likely attributable to the short half-life of this compound for the release of NO (3.1 min at $\mathrm{pH}=7.4$ ) (Morley and Keefer, 1993).

Additional evidence for the involvement of $\mathrm{NO}$ in the activation of LC cells was obtained using $\mathrm{Hb}$, a scavenger of extracellular $\mathrm{NO}$ and CO. After an initial exposure to SNP (1 mM) and the resultant increase in the $\mathrm{LC}$ firing rate, incubation of slices with $\mathrm{Hb}(100 \mu \mathrm{M})$ completely reversed the SNP effect within 5-10 min ( $n=7, p<0.0005$ ). In six of seven cells tested, $\mathrm{Hb}$ reduced the activation by SNP below the basal firing rate. Firing rates returned to previous values $-.5 \mathrm{~min}$ after $\mathrm{Hb}$ application (Fig. $3 A$ ). The specificity of the $\mathrm{Hb}$ effect was tested using MetHb, the ferric form of the protein that has substantially lower affinity for NO or CO. $\mathrm{MetHb}(100 \mu \mathrm{M})$ failed to reverse the SNP effect in the same cells in which $\mathrm{Hb}(100 \mu \mathrm{M})$ reduced the activation $(n=2$; Fig. $3 B)$. Furthermore, the $\mathrm{Hb}$ effect was selective for SNP and did not change the activation of LC neurons by other mechanisms such as by the excitatory anino acid receptor agonist AMPA $(0.6-1.3 \mu \mathrm{M})$ $(n=3)$ (data not shown).

\section{Effect of 8-Br-cGMP and 8-pCPT-cGMP on the LC firing rate}

Because cGMP is the major second messenger mediating NO effects in many systems, we tested the effect of bath-applied 8-Br-cGMP or 8-pCPT-cGMP, two membrane-permeable, phosphodiesterase-resistant analogs of cGMP, on LC firing rates. 8-Br-cGMP ( $1 \mathrm{mM}$ ) elevated the firing rate of 14 of $20 \mathrm{LC}$ cells tested. In the responsive cells, the maximal increase (Table 1) was gradually reached at $8-20 \mathrm{~min}$ and did not reverse within 15-20 min of washout (Fig. 4A). With lower concentrations of 8 -BrcGMP, a concentration-dependent effect was obtained; the maximal effect estimated by analyzing cumulative concentration-response curves $(100 \mu \mathrm{M}$ to $3 \mathrm{~mm}, 3.3 \times)$ was $218 \pm 49 \%$ over basal and the $\mathrm{EC}_{50}$ was $286 \pm 57 \mu \mathrm{M}$ ( $n=5$; Fig. 2 ). The selective activator of the cGMP-dependent protein kinase 8-pCPT-cGMP $(200-400 \mu \mathrm{M})$ also increased the firing rate of four of six LC cells tested (Table 1). In contrast to these analogs, the bath application of the endogenous nucleotide cGMP (1 mM) did not change the cell firing rate, consistent with its relatively low membrane permeability.

To evaluate whether 8-Br-cGMP activates LC cells via the same pathway as SNP, the response to SNP was studied in the presence of 8-Br-cGMP. These experiments were based on the idea that if the SNP effect occurs via an increase in the intracellular levels of cGMP, the action of SNP should be nonadditive with that of 8-Br-cGMP. After activation of LC cells by the bath application of 8-Br-cGMP (1 $\mathrm{mm})$, the additional increase in firing rate induced by SNP (1 mM) was only $33 \%$ of that in control $(n=4, p<0.0001$; Fig. $4 A$ ), indicating that the SNP effect largely is occluded by 8 -Br-cGMP. The possible interaction between SNP or 8-Br-cGMP with 8-Br-cAMP also was examined with the same protocol. Effects of either SNP (1 mM) or 8 -Br-cGMP (1 mM) also were occluded by a previous administration of 8-Br-cAMP (2 mM); that is, after 8-Br-cAMP, the SNP effect was only $26 \%(n=4, p<0.0001)$ and the 8-Br-cGMP effect was $37 \%(n=5, p<0.05)$ of that in control conditions (Fig. $4 B, C$ ). The mutual occlusion caused by the SNP, 8-Br-cGMP, and 8-Br-cAMP effects was not the consequence of the cell being maximally activated by the application of the first agent, because the increase in firing rate induced by a different mechanism (i.e., AMPA, $1.3 \mu \mathrm{M}$ ) remained the same before or after SNP administration (data not shown).

To investigate whether the 8-Br-cGMP and 8-pCPT-cGMP effects might be mediated within the postsynaptic neuron, these compounds were applied intracellularly to LC neurons via patch pipettes, and the firing rate was studied in the current-clamp mode of whole-cell recordings. Using electrodes containing 8-BrcGMP $(10-100 \mu \mathrm{M}), \mathrm{LC}$ cell firing rates were increased rapidly (1 min) to at least twice basal levels when full access to the cell was attained, allowing the nucleotide to freely diffuse into the neuron $(n=13)$. When a reduction of access ("partial access") occurred during the dialysis of the cell with the nucleotide, the activation reversed gradually within a few minutes; when full access was restored, the firing rate increased once again (Fig. 5). Similar activations of LC cells were obtained with the intracellular application of 8-pCPT-cGMP $(100 \mu \mathrm{M})$ via patch electrodes (data not shown).

\section{Effect of $\mathrm{H8}$ on LC activation}

The mechanism of SNP and 8-Br-cGMP effects was investigated further by using an inhibitor of the nucleotide-dependent protein kinases, H8, which has a preference for cGMP-dependent over cAMP-dependent protein kinase (Hidaka et al., 1984). Because the effects of SNP and 8-Br-cGMP were only very slowly reversible, there was a stable baseline against which to test the ability of H8 to reverse the LC activation produced by either of these drugs. To evaluate the selectivity of $\mathrm{H} 8$, the possible reversal by $\mathrm{H} 8$ of the 8-Br-cAMP-induced activation also was examined. After an initial exposure to SNP (1 mM), 8-Br-cGMP (1 mM), or 8-BrcAMP ( $2 \mathrm{~mm}$ ), the resultant increase in the LC firing rate (Table 1) was reversed within $8-12 \mathrm{~min}$ by incubation of slices with $\mathrm{H} 8$ $(100 \mu \mathrm{M})$. The degree of the $\mathrm{H} 8$ reversal was different for each compound: $75 \pm 11 \%$ of the SNP activation $(n=8, p<0.0005)$, $100 \pm 34 \%$ of the 8-Br-cGMP activation $(n=4, p<0.05)$, and 66 $\pm 15 \%$ of the 8 -Br-cAMP activation $(n=6, p<0.01$; Fig. 6$)$. H8 $(100 \mu \mathrm{M})$ also decreased basal firing activity (Table 1$)$; the reduc- 
A
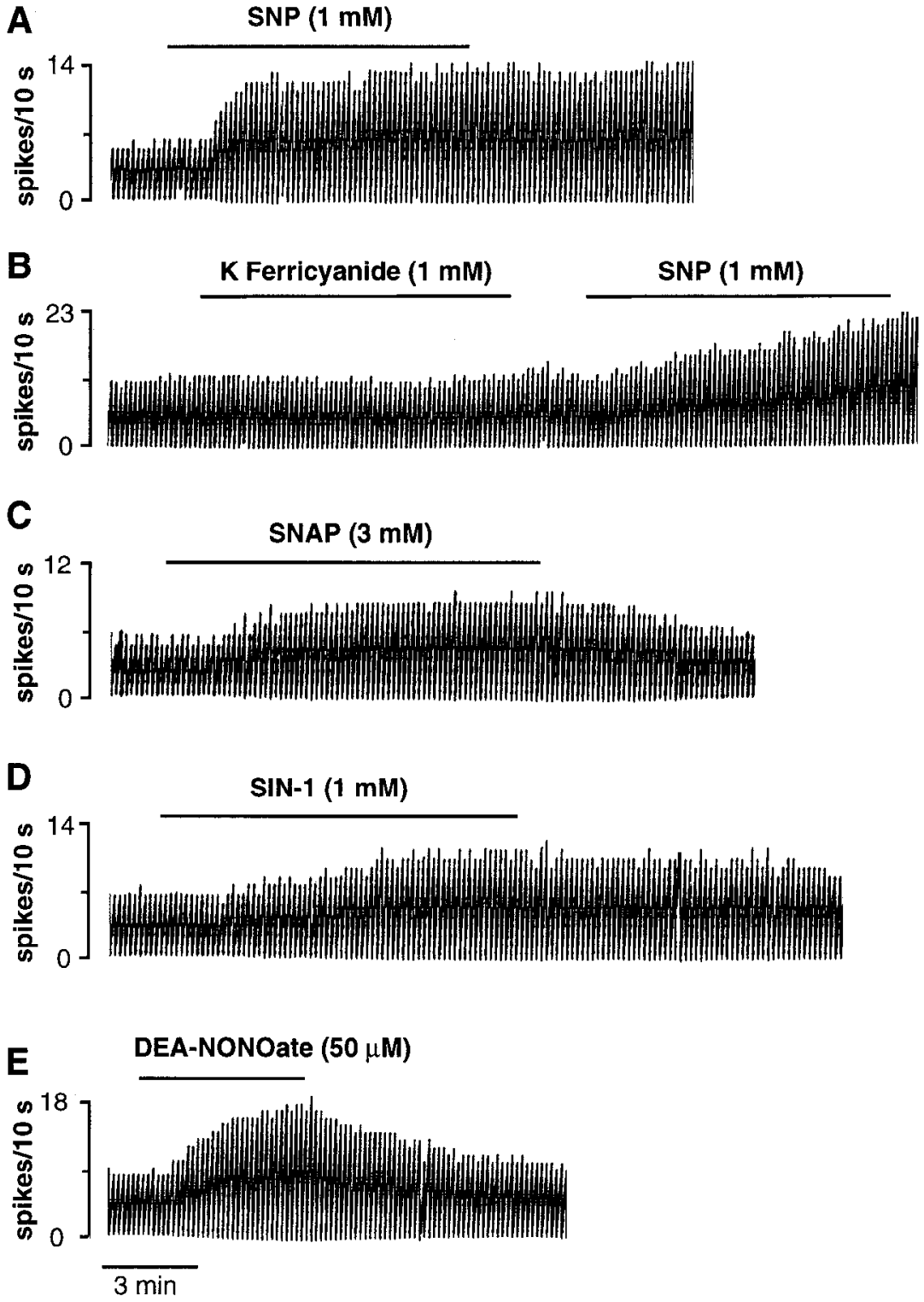

Figure 1. Firing-rate recordings of LC neurons in rat brain slices showing the effect of four different NO donors: $S N P$ $(A), K$ Ferricyanide $(B), S N A P(C)$, SIN-1 $(D)$, and DEANONOate $(E)$. Vertical lines represent firing rates extracellularly recorded and displayed on a chart recorder as integrated time histograms (spikes per $10 \mathrm{sec}$ ). The time scale applies to all traces. Drugs were bath-administered at the desired concentration for the time indicated by the horizontal bar. Note the increase in firing rate induced by all the NO donors and the slow onset with a complete (SNAP and DEA-NONOate), partial (SIN-1), or negligible (SNP) recovery of these effects. K ferricyanide, a structural analog of SNP that does not release NO, failed to change the firing rate in the same cell in which SNP increased the rate. tion of basal firing rate by $\mathrm{H} 8$ was significantly smaller $(p<0.05)$ than the reduction of the effects induced by SNP, 8-Br-cGMP, or 8-Br-cAMP (Fig. 6). A lower concentration of H8 (30 $\mu \mathrm{M})$ was able to reverse $43 \pm 8 \%$ of the SNP effect $(n=5, p<0.005)$ and $100 \pm 35 \%$ of the 8-Br-cGMP effect $(n=3, p<0.05)$, but it failed to change the activation induced by $8-\mathrm{Br}-\mathrm{cAMP}$ (change of $7 \pm$ $10 \%, n=3, p=0.29$ ) (Fig. 6).

\section{Endogenous regulation of LC firing rate by the cGMP pathway}

The observation that $\mathrm{Hb}$ reversed the SNP effect below the initial firing rate (see above) raises the question whether endogenous $\mathrm{NO}$ or $\mathrm{CO}$ might be regulating the basal activity of LC neurons. To examine this possibility, the effect of $\mathrm{Hb}$ on the basal firing activity was studied. In 31 of 32 cells tested, bath application of $\mathrm{Hb}$ $(100 \mu \mathrm{M})$ reduced the spontaneous firing rate within $4-10 \mathrm{~min}$ (Table 1 ). In 13 cells there was a complete cessation of firing during $\mathrm{Hb}$ application. This effect recovered rapidly within $5 \mathrm{~min}$ (Fig. 7A). Lower concentrations of $\mathrm{Hb}(10$ or $30 \mu \mathrm{M})$ did not modify basal activity consistently. MetHb $(100 \mu \mathrm{M})$ failed to produce any change in the same cells in which $\mathrm{Hb}(100 \mu \mathrm{M})$ reduced the basal discharge (Table 1, Fig. $7 B$ ). To investigate further the possible modulation of LC neurons by endogenously produced NO, different agents known to affect NOS were studied. Neither the NOS substrate L-arginine $(300 \mu \mathrm{M}$ to $1 \mathrm{~mm})$ nor the NOS inhibitors L-NAME $(100-300 \mu \mathrm{M})$, NMMA $(100 \mu \mathrm{M})$, or 7-NI $(100 \mu \mathrm{M})$ changed LC firing rates within $15-30 \mathrm{~min}$ of application (Table 1).

These observations indicated that the reduction of firing rate induced by $\mathrm{Hb}$ likely was not attributable to $\mathrm{NO}$ scavenging, raising the possibility that endogenously produced $\mathrm{CO}$ was involved. $\mathrm{CO}$ (100\%) was bubbled in aCSF for 30-45 min to obtain a saturated CO solution of $\sim 1 \mathrm{~mm}$, which was then applied to the slice. Because $\mathrm{CO}$ could escape from the tubing in the slice chamber, the final concentration reaching the slice was not known. In 23 of 29 cells tested, CO increased the LC firing rate within 3-10 min (Table 1). This effect recovered within 3-6 min (Fig. 8A). The activation caused by $\mathrm{CO}$ was blocked partially after a $10 \mathrm{~min}$ application of $\mathrm{H} 8$ (100 $\mu \mathrm{M}$ ) (increase in firing rate induced by $\mathrm{CO}: 72 \pm 10 \%$ before $\mathrm{H} 8$ and $29 \pm 10 \%$ after $\mathrm{H} 8$, with respect to the value immediately before 


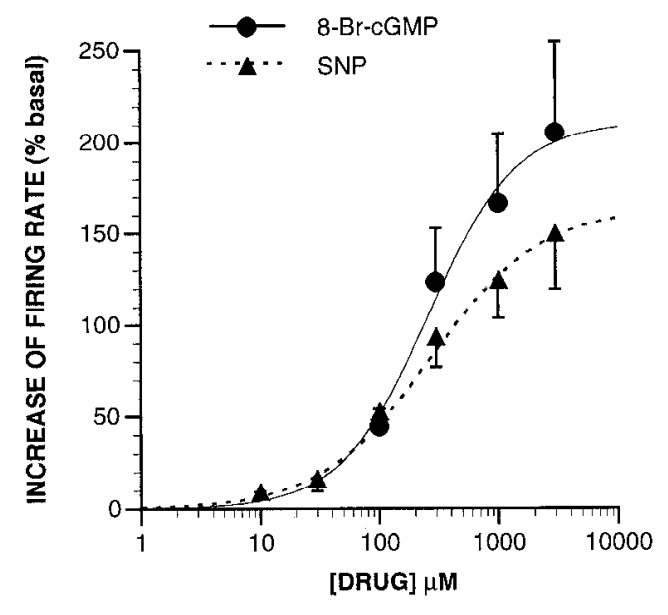

Figure 2. Cumulative concentration-response curves for the effect of SNP $(\mathbf{A}, 10 \mu \mathrm{M}$ to $3 \mathrm{mM}$ ) and the membrane-permeable cGMP analog 8-Br-cGMP (O, $100 \mu \mathrm{M}$ to $3 \mathrm{~mm}$ ) on the firing rate of LC cells extraceliularly recorded. The horizontal axis represents, in semilogarithmic scale, the bath concentration of the drug. The vertical axis shows the percentage increase of the firing rate over the baseline when the maximal effect of each concentration was reached. Symbols are mean \pm SEM of five cells. Curves are theoretical nonlinear regressions of the experimental data to the three-parameter logistic equation (see Materials and Methods). Note the concentration dependency and the saturability of these effects. The $\mathrm{EC}_{50}$ and $\mathrm{E}_{\max }$ of the regressions were $334 \pm 86 \mu \mathrm{M}$ and $185 \pm 41 \%$, respectively, for SNP and $286 \pm 57 \mu \mathrm{M}$ and $218 \pm 49 \%$, respectively, for 8 -Br-cGMP.

each CO application; $n=5, p<0.005$; Fig. $8 B$ ). This indicated the involvement of a protein kinase mechanism.

\section{Intracellular characterization of the NO-induced current}

To study the ionic mechanism underlying the NO-induced activation of LC cells, single-electrode voltage-clamp intracellular re-
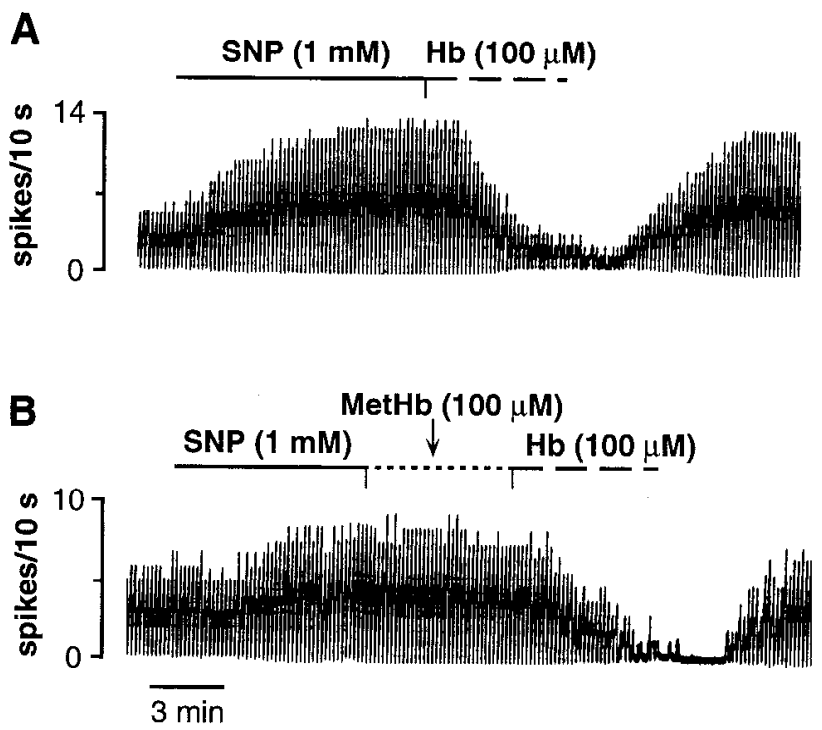

Figure 3. Firing-rate recordings of LC neurons in rat brain slices showing the reversal of SNP effect by the NO and CO scavenger $H b(A)$, but not by its inactive analog $M c t H b(B)$. Vortical lincs represent firing rates extracellularly recorded and displayed on a chart recorder as integrated time histograms (spikes per $10 \mathrm{sec}$ ). The time scale applies to both traces. Drugs were bath-administered al the desired concentration for the time indicated by the horizontal bar. Note the increase in the firing rate induced by SNP and the reversion of this activation, even below the original baseline, after $\mathrm{Hb}$. MetHb failed to reduce the firing rate in the same cell in which $\mathrm{Hb}$ was effective. Note as well the recovery of firing rates to previous values after washout of $\mathrm{Hb}$.
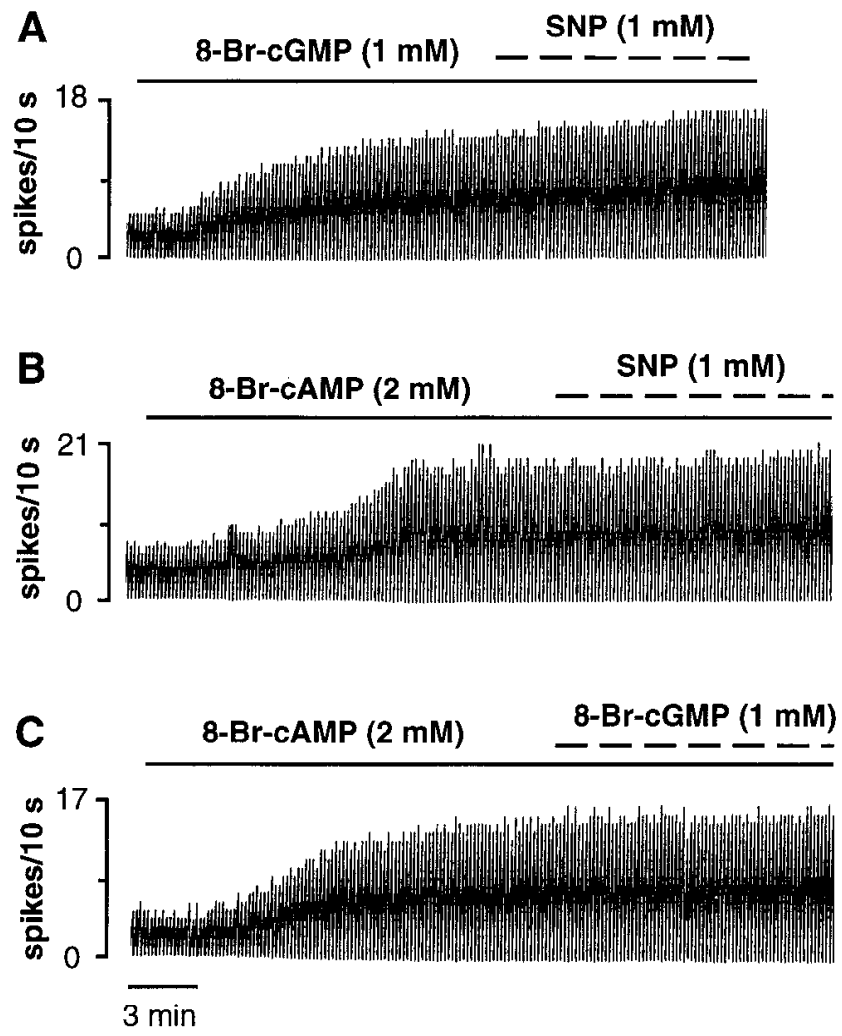

Figure 4. Firing-rate recordings of LC ncurons in rat brain slices showing the mutual occlusion of SNP, 8-Br-cGMP, and 8-Br-cAMP effects: SNP activation was occluded by 8-Br-cGMP $(A)$ or 8 -Br-cAMP $(B) ; 8-\mathrm{Br}$ cGMP activation was occluded by 8 -Br-cAMP $(C)$. Vertical lines represent firing rates extracellularly recorded and displayed on a chart recorder as integrated time histograms (spikes per $10 \mathrm{sec}$ ). The time scale applies to all traces. Drugs were bath-administered at the desired concentration for the time indicated by the horizontal bar. Note the increase in the firing rate induced by SNP, 8-Br-cGMP, and 8-Br-cAMP and the lack of additivity of activation by concurrent applications of these compounds.

cordings were performed. For this purpose, DEA-NONOate was chosen as the NO donor because of its larger and more consistent maximal effect and the faster recovery of the response. Under baseline conditions, the mean holding current at $-60 \mathrm{mV}$ was $-93 \pm 19 \mathrm{pA}$, and the input resistance was $101 \pm 11 \mathrm{M} \Omega(n=13)$. While the membrane potential was clamped at $-60 \mathrm{mV}$, bath application of DEA-NONOate $(50 \mu \mathrm{m})$ resulted in an inward current with an increase in apparent input conductance. The amplitude of this current was $33+4 \mathrm{pA}(n=13, p<0.001)$. The onset and recovery of the current induced by DEA-NONOate exhibited a similar time course to the increase in firing rate produced by this drug (Fig. $9 \hat{A}$ ). Current-voltage $(I-V)$ relations were determined before and during the application of DEANONOate by applying slow hyperpolarizing ramps from a holding potential of $-60 \mathrm{mV}$ to $-120 \mathrm{mV}$ (the latter is beyond the approximate reversal potential of $\mathrm{K}^{+}$in $\mathrm{LC}$ cells with $3 \mathrm{~mm}$ external $\mathrm{K}^{+}$). As illustrated in Figure $9 A$, DEA-NONOate generated a progressive increase in the magnitude of the inward current throughout the voltage range used. The net current activated by DEA-NONOate over this range was obtained by subtracting the basal current from that recorded in the presence of the drug (Fig. 9A). The relationship between the voltage and the DEA-NONOate-activated current (subtracted current) was apparently monotonic, indicating that the conductance underlying 

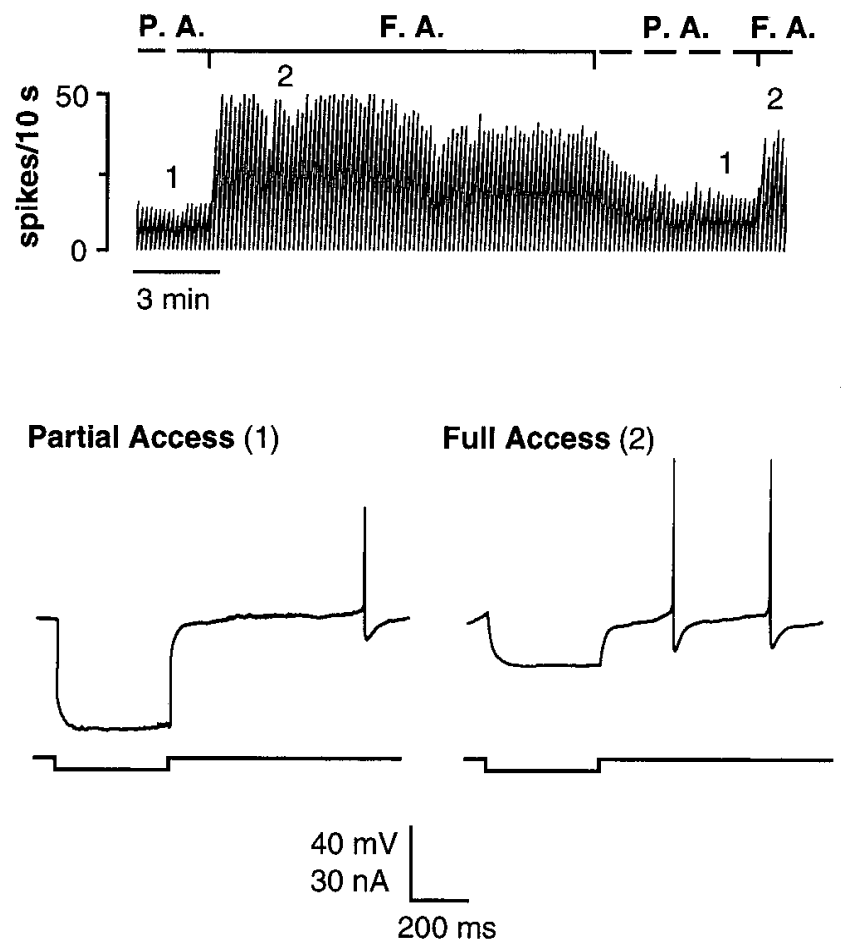

Figure 5. Whole-cell palch-clann recor ding of an LC neuron showing the effect of the intracellular application of 8-Br-cGMP $(100 \mu \mathrm{M})$ on the firing rate. Vertical lines represent firing rates displayed on a chart recorder as integrated time histograms (spikes per $10 \mathrm{sec}$ ). 8 - Br-cGMP was present at the desired concentration in the patch electrode. The basal firing rate was recorded before attaining the full access to the cell when the dialysis with 8-Br-cGMP is still limited (i.e., partial access or P.A. $=36.8 \mathrm{M} \Omega$ ). After the full access occurred $(F . A .=3 \mathrm{M} \Omega)$, the cell was activated rapidly and strongly because of the free diffusion of 8 -Br-cGMP. The resumption of the partial or full access resulted in equivalent effects. Oscilloscope traces of action potentials and the voltage responses to a hyperpolarizing current step also were obtained in the same LC in the partial (1) or full (2) access periods. Note the increase in the spike amplitude and the decrease in the total resistance after attaining the full access.

this current is voltage-independent in the potential range of -120 to $-60 \mathrm{mV}$. The slope conductance of the DEA-NONOateactivated current, estimated from the fitting of the subtracted $I-V$ relation to a straight line, was $-1.2 \pm 0.1 \mathrm{pA} / \mathrm{mV}$ (i.e., $-1.2 \mu \mathrm{S}$, $n=13$ ). According to this protocol, the mean inward current induced by DEA-NONOate at $-90 \mathrm{mV}$ was $69 \pm 5 \mathrm{pA}$, and the extrapolated reversal potential was $-27 \pm 6 \mathrm{mV}(n=13)$. (It should be noted that it was not fcasible to determine directly an experimental reversal potential for the DEA-NONOate response because the blockade of $\mathrm{Ca}^{2+} / \mathrm{K}^{+}$currents that are generated in the same potential range had complex effects.) The current generated by DEA-NONOate was observed in cells either with or without spontaneous current oscillations (Williams et al., 1984). The blocker of fast voltage-dependent $\mathrm{Na}^{+}$channels TTX $(2 \mu \mathrm{M})$ failed to affect the DEA-NONOale-aclivaled current as could be seen in the subtracted $I-V$ ramps for the NO donor before or after TTX treatment $(n=1)$ (data not shown).

The properties of the current induced by DEA-NONOate (reduced input resistance, reversal potential near $-30 \mathrm{mV}$, apparent voltage independence, and TTX insensitivity) suggest that a gating of nonselective cationic channels might be responsible for the inward current observed in LC cells. To test the possibility that $\mathrm{Na}$ ions carry this current through TTX-insensitive channels, a low

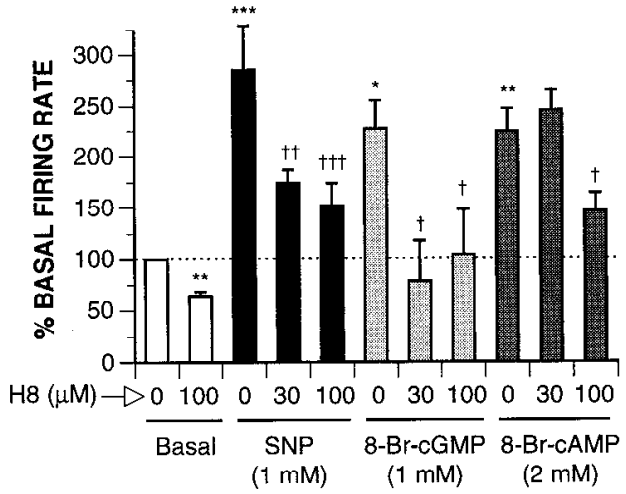

Figure 6. Reversal of the SNP, 8-Br-cGMP, and 8-Br-cAMP effects by different concentrations of the inhibitor of nucleotide-dependent protein kinases H8 (30 and $100 \mu \mathrm{M}$ ) in LC neurons. SNP, 8-Br-cGMP, and 8-Br-cAMP were applied first $(\mathrm{H} 8=0 \mu \mathrm{M})$, and after the maximal activation of the cell was achieved, $\mathrm{H} 8(30$ and $100 \mu \mathrm{M})$ was coadministered with each compound. The horizontal axis represents the bath concentration of drugs. The vertical axis shows the percentage of the basal firing rate (Basal $=100 \%)$. Bars are mean \pm SEM of three to eight cells. ${ }^{*} p<0.05 ;{ }^{*} p<0.01 ;{ }^{* * *} p<0.001$ when the absolute firing rates before versus during $S N P, 8-B r-c G M P$, or $8-B r-c A M P$ applications are compared by a two-tailed paired Student's $t$ test. $\dagger p<0.05$; ††p $<0.005$; $\dagger \dagger p<$ 0.001 when the absolute firing rates before versus after $\mathrm{H} 8$ applications are compared by a two-tailed paired Student's $t$ test. Note that the higher concentration of $\mathrm{H} 8$ reversed the activation induced by SNP, 8-Br-cGMP, or 8-Br-cAMP, but only the SNP and 8-Br-cGMP effects were reversed by the lower concentration of $\mathrm{H} 8$. $\mathrm{H} 8$ also reduced the basal firing rate.

$\mathrm{Na}^{+}$-containing aCSF was used, with $80 \%$ of the $\mathrm{Na}^{+}$replaced by Tris- $\mathrm{HCl}$ (aCSF-Tris). In LC cells voltage-clamped at $-60 \mathrm{mV}$, perfusion of slices with aCSF-I'ris caused an outward current of $210 \pm 31 \mathrm{pA}$ and a complete cessation of the spontaneous current oscillations. There was a rapid recovery (a few minutes) of these effects after switching back to standard aCSF $(n=3)$. In the presence of aCSF-Tris, the DEA-NONOate-activated current was abolished totally; that is, in the same cells in which bath-applied DEA-NONOate $(50 \mu \mathrm{M})$ induced a $34 \pm 8 \mathrm{pA}$ inward current at $-60 \mathrm{mV}$ in standard aCSF, this drug failed to change the holding current or the $I-V$ ramps in aCSF-Tris $(n=3$; Fig. $9 B)$. The elimination of the DEA-NONOate current by $\mathrm{Na}^{+}$substitution occurred either in oscillatory or nonoscillatory LC cells, indicating that this effect was not related to the blockade of oscillations promoted by aCSF-Tris.

\section{Effect of DEA-NONOate on LC synaptic currents}

The previous experiments using intracellular applications of $8-\mathrm{Br}$ cGMP or 8-pCPT-cGMP indicated that the effect induced by this nucleotide could be mediated directly at the postsynaptic level. However, because NO can mediate its effects in other brain areas through the release of neurotransmitters (see Discussion), it also is possible that the activation of LC neurons elicited by NO could be partly attributable to the release of excitatory endogenous substances. To investigate this hypothesis, PSCs of LC neurons were studied by whole-cell patch-clamp recording bcforc and during the DEA-NONOate application. In the control conditions with the potential clamped at $-60 \mathrm{mV}$, LC neurons exhibited relatively few spontaneous inward PSCs (about 6-15 PSCs/10 sec) with amplitudes up to $\sim 100 \mathrm{pA}$. Because the electrodes contained gluconate, which does not permeate chloride channels readily, these inward currents are presumably EPSCs rather than reverse IPSCs. As seen previously with intracellular recordings, the bath application of DEA-NONOate $(50 \mu \mathrm{M})$ resulted in an inward 
A

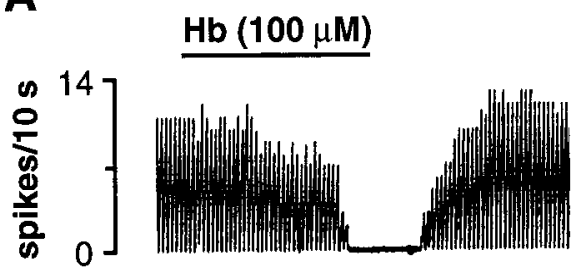

B
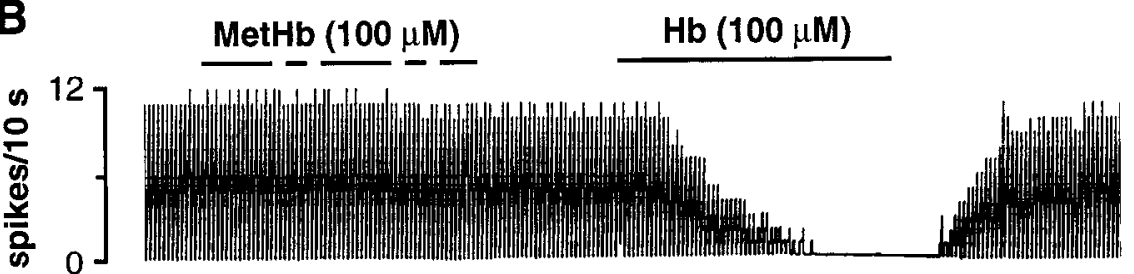

$3 \min$
Figure 7. Firing-rate recordings of LC neurons in rat brain slices showing the reduction of the spontaneous firing activity by $H b(A)$, but not by $\operatorname{MetHb}(B)$. Vertical lines represent firing rates extracellularly recorded and displayed on a chart recorder as integrated time histograms (spikes per $10 \mathrm{sec}$ ). The time scale applies to both traces. Drugs were bathadministered at the desired concentration for the time indicated by the horizontal bar. Note the complete cessation of the firing rate during $\mathrm{Hb}$ application and the recovery of the effect. MetHb failed to change the firing rate in the same cell in which $\mathrm{Hb}$ was effective. current of 50-100 pA, with an increase in apparent input conductance ( $n=4$; Fig. 10 ). At the peak of the DEA-NONOateinduced effect, there was no consistent change in the number of EPSCs with respect to the amount of these at the basal period (reduction of EPSCs in two cells, increase in one cell, and no change in one cell) (Fig. 10)

\section{DISCUSSION}

The present study shows that NO and CO can activate the firing rate of most noradrenergic neurons of the LC. Evidence is presented that this activation occurs via a cGMP- and cGMPdependent protein kinase pathway. In addition, the activation of LC neurons by NO is shown to be associated with an inward current with features characteristic of a nonselective cationic channel. This effect is mediated primarily at the postsynaptic level on LC neurons because intracellular applications of cGMP analogs are able to activate these cells, whereas the number and amplitude of synaptic currents do not appear to be changed by NO donors. It also is proposed that there may be a tonic regulation of LC neurons via the cGMP pathway.

\section{Activation of LC neurons by NO}

Two different findings indicate that NO activates LC neurons. First, four structurally unrelated NO donors (SNP, SNAP, SIN-1, and DEA-NONOate) were able to increase the firing rate of LC cells in a concentration-related manner; potassium ferricyanide, a structural analog of SNP lacking NO donating properties, did not affect the cell firing rate. Second, the effect of SNP was reversed by the NO scavenger $\mathrm{Hb}$ (ferrous form) but not by the ferric form of the same protein (MetHb), which exhibits a low affinity for this gas (Murphy and Noack, 1994). The Hb elfect was selective for $\mathrm{NO}$ donors because $\mathrm{Hb}$ failed to reverse the $\mathrm{LC}$ activation induced by other mechanisms (i.e., AMPA). SNAP (Southam and Garthwaite, 1991; Morley and Keefer, 1993) and DEA-NONOate (Morley and Keefer, 1993) are believed to release NO spontaneously by simple dissociation. SIN-1 undergoes conversion to SIN$1 \mathrm{~A}$, which then decomposes spontaneously to $\mathrm{NO}$ and the inactive SIN-1C (Feelisch and Noack, 1987). SNP has been shown to yield NO either in a tissue-dependent manner (Ignarro et al., 1981; Morley and Keefer, 1993) or spontaneously (Feelisch and Noack, 1987; Niroomand et al., 1991) in different experimental condi-
A

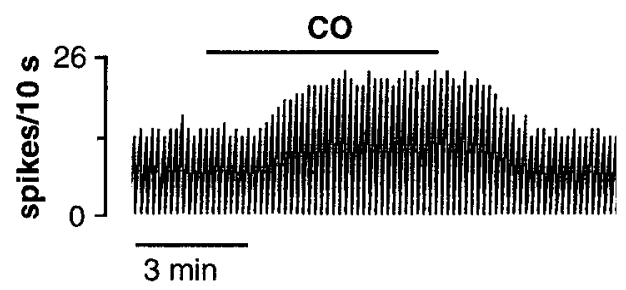

B

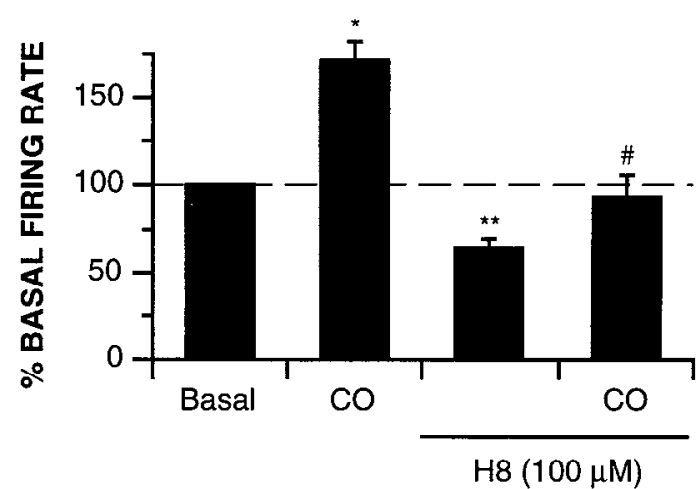

Figure 8. A, Firing-rate recording of an LC neuron showing the effect of CO. Vertical lines represent the firing rates extracellularly recorded and displayed on a chart recorder as integrated time histograms (spikes per 10 sec). CO was first bubbled in aCSF for 30-45 min to obtain a saturated concentration of the gas $(\sim 1 \mathrm{~mm})$ and then bath-administered for the time indicated by the horizontal bar. (Because no attempt was made to reduce loss of $\mathrm{CO}$ in the tubing, the final concentration of $\mathrm{CO}$ is not known.) Note the activation of the cell by $\mathrm{CO}$, and the complete recovery of this effect. $B$, Partial blockade of $\mathrm{CO}$ effect by previous application of $\mathrm{H} 8$ in $\mathrm{LC}$ neurons. In each cell, CO-containing aCSF was administered before and after H8. The horizontal axis represents the application of drugs. The verfical axis shows the percentage of the basal firing rate (Basal $=100 \%$ ). Bars are mean \pm SEM of five cells. ${ }^{*} p<0.05 ;{ }^{* *} p<0.01$ when the absolute firing rates before versus after $\mathrm{CO}$ applications or before versus after $\mathrm{H} 8$ application are compared by a two-tailed paired Student's $t$ test. $\# p<0.005$ when the absolute increases in the firing rate induced by $\mathrm{CO}$ before versus after $\mathrm{H} 8$ applications are compared by a two-tailed paired Student's $t$ test. Note that the activation of LC cells by CO was smaller after $\mathrm{H} 8$ application. $\mathrm{H} 8$ also reduced basal firing rate. 
A
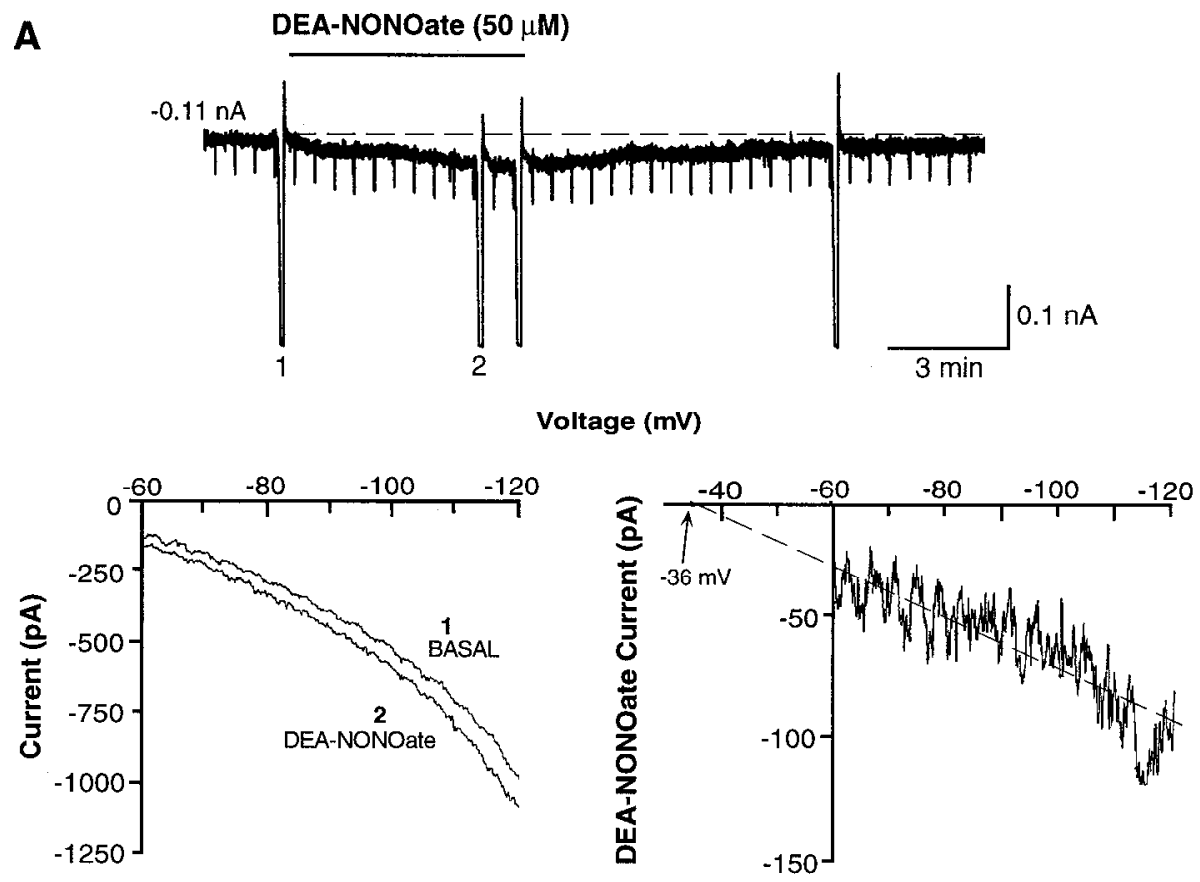

B

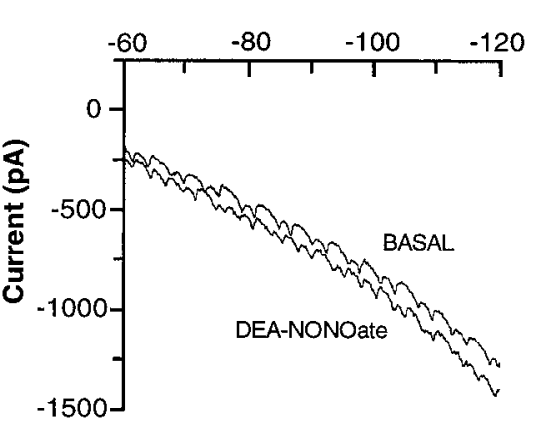

Standard aCSF
Voltage (mV)

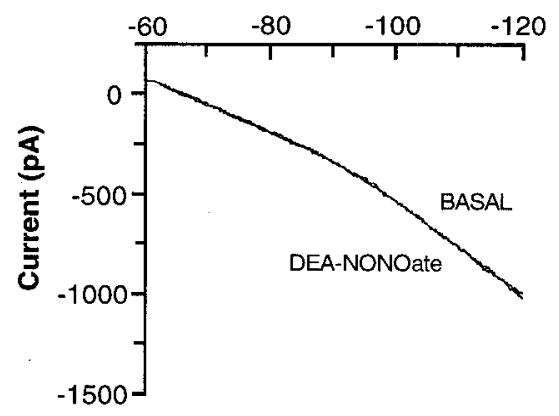

Low sodium
Figure 9. A, Intracellular voltage-clamp recording of an LC cell clamped at $-60 \mathrm{mV}$ showing the effect of $D E A$-NONOate. The holding current was recorded with a chart recorder before, during (horizontal bar), and after the bath administration of DEA-NONOate (top). The apparent input conductance was obtained by $6 \mathrm{mV}$ hyperpolarizing steps of $1 \mathrm{sec}$ duration each. Note the inward current with the slight increase in input conductance induced by DEANONOate, and the complete recovery of these effects. Current-voltage relations (left) were determined before $(I)$ and during (2) the application of DEA-NONOate by recording the current responses (vertical axis) to slow hyperpolarizing ramps from a holding potential of $-60 \mathrm{mV}$ to $-120 \mathrm{mV}$ (horizontal axis). The net current activated by DEA-NONOate (right) also was obtained by subtracting the basal current from that recorded in the presence of the drug (DEANONOate current). The reversal potential was obtained by fitting the voltage-DEA-NONOate current relation to a straight line and extrapolating this line to 0 . Note that DEA-NONOate generated a progressive increase in the magnitude of the inward current throughout the voltage range used (increased slope-conductance). The relationship between the voltage and the DEA-NONOate current was apparently monotonic with an extrapolated reversal potential of $-36 \mathrm{mV} . B$, Current-voltage relations before and during the application of DEA-NONOate in standard (left) or low- $\mathrm{Na}^{+}$aCSF $(80 \%$ of the $\mathrm{Na}^{+}$concentration replaced by Tris-HCl) $($right $)$. In the presence of low- $\mathrm{Na}^{+}$aCSF, the holding current shifted to positive values and the inward current induced by DEA-NONOate was blocked completely. tions. NO released from SNP or SNAP occurs in a $\mathrm{pH}$ independent manner, whereas that from DEA-NONOate and SIN-1 is maximal in acidic and basic solutions, respectively (Feelisch and Noack, 1987; Morley and Keefer, 1993). All these observations along with the rapid inactivation of $\mathrm{NO}$ in slice preparations (Southam and Garthwaite, 1991) might be important factors in explaining the variability or lack of response to these NO donors observed in some LC neurons (Table 1). Alternatively, it is possible that LC neurons are not homogeneous with respect to their responses to NO.

\section{Involvement of cGMP and cGMP-dependent protein kinase in the effect of NO}

In brain slices, NO released from SNP, SNAP, or SIN-1 has been shown to activate soluble guanylate cyclase and to increase the intracellular levels of cGMP (Arnold et al., 1977; Southam and Garthwaite, 1991; Boulton et al., 1994); DEA-NONOate also stimulates guanylate cyclase in vascular tissues (Morley and Keefer, 1993). Various potential mechanisms can account for the effects of cGMP in different systems (see introductory remarks). In the present study, experiments were performed with activators
(8-Br-cGMP and 8-pCPT-cGMP) or inhihitors (H8) of cGMPdependent protein kinase to characterize the pathway involved in $\mathrm{NO}$ effect. The bath and intracellular application of 8-Br-cGMP resulted in concentration-dependent increases in LC cell firing rate. The time course and magnitude of the maximal effect induced by 8 -Br-cGMP resembled those by SNP; after the application of 8-Br-cGMP, there was an occlusion of SNP effect (nonadditivity). Bath or intracellularly applied 8-pCPT-cGMP also increased the cell firing rate. 8-Br-cGMP and 8-pCPT-cGMP are two membrane-permeable, phosphodiesterase-resistant analogs of cGMP. 8-Br-cGMP exhibits $\sim 1200$-fold higher selectivity for cGMP-dependent protein kinase than for cAMP-dependent protein kinase (Butt et al., 1992). Additionally, 8-pCPT-cGMP has a negligible activity on either cGMP-inhibited or cGMP-activated phosphodiesterases. Responses induced by SNP and 8-Br-cGMP were reversed by either of two concentrations of $\mathrm{H} 8$ (30 and 100 $\mu \mathrm{M})$, whereas only a high concentration of H8 $(100 \mu \mathrm{M})$ was able to affect the 8-Br-cAMP response. $\mathrm{H} 8$ is an inhibitor of the cyclic nucleotide dependent protein kinases with a 2.5 fold higher affinity for the cGMP-dependent over the cAMP-dependent protein 


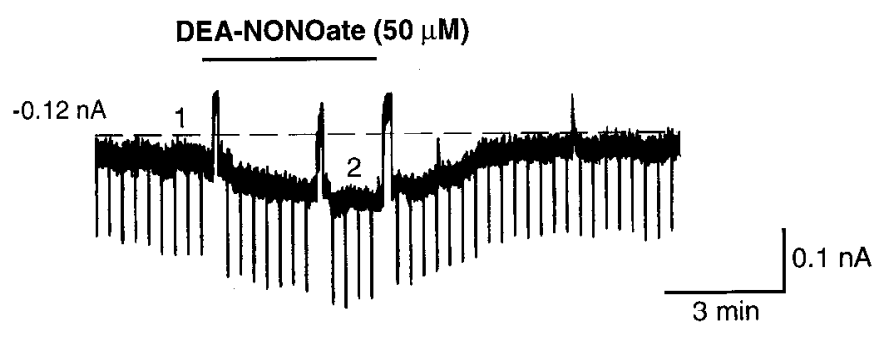

BASAL (1)

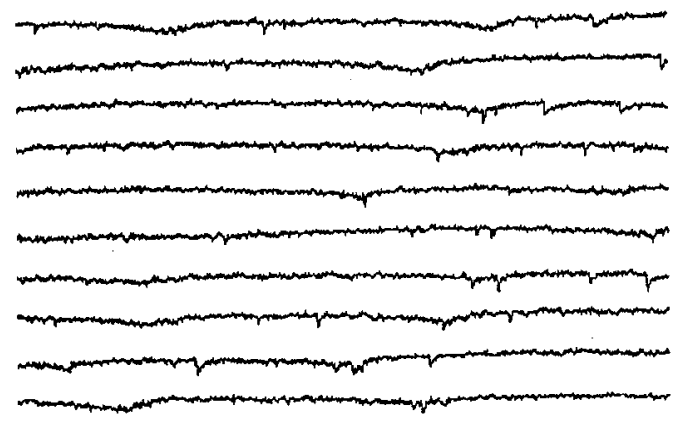

DEA-NONOate (2) $\overline{100 \mathrm{~ms}}^{200 \mathrm{pA}}$

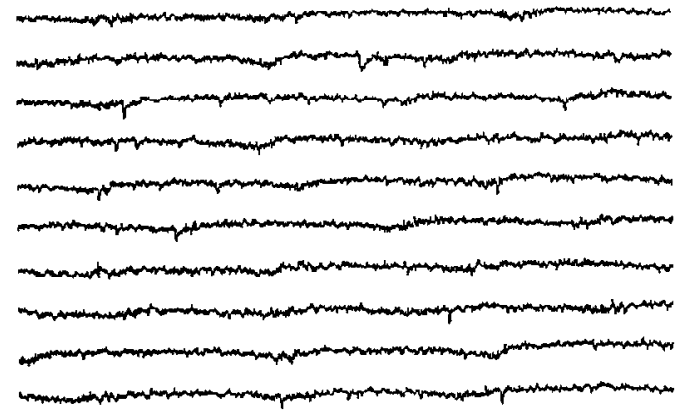

Figure 10. Whole-cell voltage-clamp recording of an LC cell clamped at $-60 \mathrm{mV}$ showing the effect of DEA-NONOate. The holding current was recorded with a control patch electrode before, during (horizontal bar), and after the bath administration of DEA-NONOate using a chart recorder (top). The apparent input conductance was obtained by $10 \mathrm{mV}$ hyperpolarizing steps of $1 \mathrm{sec}$ duration each. Note the inward current and the increase in input conductance induced by DEA-NONOate. PSCs obtained before $(1$, middle $)$ and during administration of DEA-NONOate $(2$, bottom) were recorded from 10 successive episodes ( $1 \mathrm{sec}$ duration each) by means of PCLAMP. Note the presence of a few spontaneous, low-amplitude, inward PSCs (excitatory PSCs). The number and amplitude of these EPSCs were not affected by DEA-NONOate.

kinase (Hidaka et al., 1984). Therefore, all these data support the idea that activation of LC cells by NO is mediated via a cGMPand a cGMP-dependent protein kinase pathway. Consistent with this idea, a high density of $\alpha_{1}$ and $\beta_{1}$ subunits of the soluble guanylate cyclase (Matsuoka et al., 1992; Furuyama et al., 1993) and of the type II cGMP-dependent protein kinase (El-Husseini ct al., 1995) have becn found in LC.

\section{Mediation of the NO effect at the postsynaptic level}

It has been proposed that some of the postsynaptic effects of the NO-generating agents in the CNS are mediated indirectly by the modulation of presynaptic terminals (Garthwaite, 1991; Montague et al., 1994). In the LC, a role for NO in the modulation of evoked synaptic transmission also has been demonstrated ( $\mathrm{Xu}$ et al., 1994). In the present study, it was found that the intracellular application of 8-Br-cGMP or 8-pCPT-cGMP via patch electrodes resulted in activations of $\mathrm{LC}$ cells, suggesting that the modulation of LC neurons by cGMP can be exerted directly at the postsynaptic lcvel. Morcover, spontancous EPSCs wcre not incrcased by the application of DEA-NONOate in the same cells in which the drug induced a consistent inward current. TTX failed to change the DEA-NONOate-activated current, ruling out a modulation by $\mathrm{NO}$ of any impulse-dependent release. Together with the observation that the mRNA for guanylate cyclase is present in LC cells (Furuyama et al., 1993), these findings strongly suggest that the regulation of LC neurons by the NO/CGMP pathway occurs primarily at a postsynaptic level.

\section{Characterization of the NO-induced current}

To identify the current associated with the activation of LC cells by $\mathrm{NO}$, voltage-clamp intracellular recordings were performed. DEA-NONOate promoted an inward current along with an increase in apparent input conductance. Hyperpolarizing $I-V$ ramps revealed that the DEA-NONOate-induced current was monotonic, likely because of the activation of a voltage-independent conductance, with an estimated reversal potential of $-27 \mathrm{mV}$. This current, found either in oscillatory or nonoscillatory cells, was not modified by TTX application. A TTX-insensitive inward current with a similar reversal potential would be consistent with the opening of a nonselective cationic channel (Connor and Hockberger, 1984). However, similar electrophysiological features also are compatible with the gating of a $\mathrm{Cl}^{-}$chanuel (using high $\mathrm{KCl}$-containing electrodes) or the activation of an electrogenic $\mathrm{Na}^{+}-\mathrm{Ca}^{2+}$ exchanger (Ehara et al., 1989). In fact, in neuronal preparations, $\mathrm{NO}$ is capable of stimulating the $\mathrm{Na}^{+}-\mathrm{Ca}^{2+}$ exchange in a cGMP-dependent manner (Asano et al., 1995). Therefore, to discriminate among these mechanisms, some experiments were conducted by manipulating the external concentration of $\mathrm{Na}^{\prime}$. When $80 \%$ of $\mathrm{Na}^{\prime}$ was replaced by Tris- $\mathrm{HCl}$, the response to DEA-NONOate was abolished totally, indicating that the NO-induced current is carried strongly by $\mathrm{Na}^{+}$. Because decreasing the extracellular concentration of $\mathrm{Na}^{+}$shifts the reversal potential of the $\mathrm{Na}^{+}-\mathrm{Ca}^{2+}$ exchanger current in the hyperpolarizing direction, causing an outward rather than an inward current (when the cell is clamped at $-60 \mathrm{mV}$ ) (Ehara et al., 1989), the involvement of an $\mathrm{Na}^{+}-\mathrm{Ca}^{2+}$ exchanger can be ruled out. Furthermore, DEA-NONOate produced a similar inward current when the experiment was performed with low $\mathrm{Cl}^{-}$-containing electrodes (patch electrodes), making the possibility of a $\mathrm{Cl}^{-}$ channel very unlikely. Taken together, the present results suggest that activation of a nonselective cationic channel may be the mechanism underlying the NO effect.

In LC neurons, it also has been shown that a nonselective cationic channel is modulated by a cAMP-dependent phosphorylation pathway (Wang and Aghajanian, 1987, 1990; Alreja and Aghajanian, 1991). Thus, a nonselective cationic channel might be the final common target for cGMP and CAMP pathways in LC cells. This possibility would correspond well with the observation that 8-Br-cAMP occluded SNP and 8-Br-cGMP effects (nonadditivity). A TTX-insensitive $\mathrm{Na}^{+}$-dependent inward current also has been reported to be activated by cGMP in Aplysia (Sawada et al., 1995) or gastropod (Connor and Hockberger, 1984) neurons. Likewise, in thalamocortical neurons of mammalian brain slices, release of NO modulates the hyperpolarization-activatcd cation current probably via the cGMP system (Pape and Mager, 1992). 


\section{Physiological relevance: identification of an endogenous activator of guanylate cyclase in LC}

NOS appears to be expressed in neurons of brainstem but not in noradrenergic cclls of LC (Vincent and Kimura, 1992; Johnson and Ma, 1993; Dun et al., 1994). A recent report has confirmed these findings, showing that NOS-like immunoreactivity is present in nuclei adjacent to LC, but only in few cell bodies and dendritic and axonal processes within the LC (Xu et al., 1994). Despite the apparent paucity of NOS, high levels of soluble guanylate cyclase are present in LC (Furuyama et al., 1993) and potentially could respond to NO formed in areas surrounding the $\mathrm{LC}$, as shown in other systems (Giuili et al., 1994). Therefore, the question arises whether NO might play a role in the tonic regulation of LC. As a first approach, bath application of $\mathrm{Hb}$ strongly reduced the basal firing rate of $\mathrm{LC}$ cells. The effect of $\mathrm{Hb}$ was not mimicked by MetHb, implying that there is an endogenous, diffusible molecule with a high affinity for the ferrous group of $\mathrm{Hb}$ that contributes in the tonic maintenance of the $\mathrm{LC}^{-}$discharge. $\mathrm{H} 8$ also produced a small but significant reduction in the basal firing activity. Surprisingly, neither the stimulation of NOS with L-arginine (Palmer ct al., 1988) nor the inhibition of NOS with L-NAME, NMMA, or 7-NI (Rees et al., 1990; Moore et al., 1993; Knowles and Moncada, 1994) caused any change in LC firing rate. These data argue against $\mathrm{NO}$ as the endogenous substance that activates guanylate cyclase in LC cells.

$\mathrm{CO}$ has emerged as another diffusible messenger in CNS (Marks el al., 1991; Maines, 1993; Stevens and Wang, 1993; Zhuo et al., 1993), which also activates guanylate cyclase in different tissues, including the CNS (Ramos et al., 1989; Verma et al., 1993). In the present study, bath application of $\mathrm{CO}$ also increased LC firing rate. This activation was prevented by H8, indicating the involvement of a nucleotide-dependent protein kinase in this effect. Because $\mathrm{CO}$ possesses a high affinity for $\mathrm{Hb}$, it is possible that this gas is the endogenous activator of the guanylate cyclase in LC. Additional experiments are needed to test this hypothesis.

\section{REFERENCES}

Alreja M, Aghajanian GK (1991) Pacemaker activity of locus coeruleus neurons: whole-cell recordings in brain slices show dependence on cAMP and protein kinase A. Brain Res 556:339-343.

Andrade R, Vandermaelen CP, Aghajanian GK (1983) Morphine tolerance and dependence in the locus coeruleus: single cell studies in brain slices. Eur J Pharmacol 91:161-169.

Arnold WP, Mittal CK, Katsuki S, Murad F (19/7) Nitric oxide activates guanylate cyclase and increases guanosine $3^{\prime}: 5^{\prime}$-cyclic monophosphate levels in various tissue preparations. Proc Natl Acad Sci USA 74:3203-3207.

Asano S, Matsuda T, Takuma K, Kim HS, Sato T, Nishikawa T, Baba A (1995) Nitroprusside and cyclic GMP stimulate $\mathrm{Na}^{+}-\mathrm{Ca}^{2+}$ exchange activity in neuronal preparations and cultured rat astrocytes. J Neurochem 64:2437-2441.

Boulton CL, Irving AJ, Southam E, Potier B, Garthwaite J, Collingridge GL (1994) The nitric oxide-cyclic GMP pathway and synaptic depression in rat hippocampal slices. Eur J Neurosci 6:1528-1535.

Bredt DS, Glatl CE, Hwang PM, Fotuslii M, Dawsun TM, Sinyder SH (1991) Nitric oxide synthase protein and mRNA are discretely localized in neuronal populations of the mammalian CNS together with NADPH diaphorase. Neuron 7:615-624.

Bruhwyler J, Chleide E, Liegeois JF, Carreer F (1993) Nitric oxide: a new messenger in the brain. Neurosci Biobehav Rev 17:373-384.

Butt E, Nolte C, Schulz S, Beltman J, Beavo JA, Jastorff B, Walter U (1992) Analysis of the functional role of cGMP-dependent protein kinase in intact human platelets using a specific activator 8-parachlorophenylthio-cGMP. Biochem Pharmacol 43:2591-2600.

Connor JA, Hockberger P (1984) A novel membrane sodium current induced by injection of cyclic nucleotides into gastropod neurones. $\mathrm{J}$ Physiol (Lond) 354:139-162.
Dawson TM, Snyder SH (1994) Gases as biological messengers: nitric oxide and carbon monoxide in the brain. $J$ Neurosci 14:5147-5159.

De Lean A, Munson PJ, Rodbard D (1978) Simultaneous analysis of families of sigmoidal curves: application to bioassay, radioligand assay, and physiological dose-response curves. Am J Physiol 235:E97-E102.

Dun NJ, Dun SL, Forstermann U (1994) Nitric oxide synthase immunoreactivity in rat pontine medullary neurons. Neuroscience 59:429-445.

Ehara T, Matsuoka S, Noma A (1989) Measurement of reversal potential of $\mathrm{Na}^{+}-\mathrm{Ca}^{2+}$ exchange current in single guinea-pig ventricular cells. J Physiol (Lond) 410:227-249.

El-Husseini A, Bladen C, Vincent R (1995) Molecular characterization of a type II cyclic GMP-dependent protein kinase expressed in the rat brain. J Neurochem 64:2814-2817.

Feelisch M, Noack EA (1987) Correlation between nitric oxide formation during degradation of organic nitrates and activation of guanylate cyclase. Eur J Pharmacol 139:19-30.

Fesenko EE, Kolesnikov SS, Lyubarsky AL (1985) Induction by cyclic GMP of cationic conductance in plasma membrane of retinal rod outer segment. Nature 313:310-313.

Furuyama T, Inagaki S, Takagi H (1993) Localizations of alpha 1 and beta 1 subunits of soluble guanylate cyclase in the rat brain. Mol Brain Res 20:335-344.

Garthwaite J (1991) Glutamate, nitric oxide and cell-cell signalling in the nervous systern. Trends Neurusci 14:60-67.

Garthwaite J, Charles SL, Chess-Williams R (1988) Endotheliumderived relaxing factor release on activation of NMDA receptors suggests role as intercellular messenger in the brain. Nature 336:385-388.

Giuili G, Luzi A, Poyard M, Guellaen G (1994) Expression of mouse brain soluble guanylyl cyclase and NO synthase during ontogeny. Develop Brain Res 81:269-283.

Hidaka H, Inagaki M, Kawamoto S, Sasaki Y (1984) Isoquinolinesulfonamides, novel and potent inhibitors of cyclic nucleotide dependent protein kinase and protein kinase C. Biochemistry 23:5036-5041.

Ignarro LJ, Lippton H, Edwards JC, Baricos WH, Hyman AL, Kadowitz PJ, Gruetter CA (1981) Mechanism of vascular smooth muscle relaxation by organic nitrates, nitrites, nitroprusside and nitric oxide: evidence for the involvement of S-nitrosothiols as active intermediates. J Pharmacol Exp Ther 218:739-749.

Johnson MD, Ma PM (1993) Localization of NADPH diaphorase activity in monoaminergic neurons of the rat brain. J Comp Neurol 332:391-406.

Knowles RG, Moncada S (1994) Nitric oxide synthases in mammals. Biochem J 298:249-258.

Maines MD (1993) Carbon monoxide: an emerging regulator of cGMP in the brain. Mol Cell Neurosci 4:389-397.

Marks GS, Brien JF, Nakatsu K, McLaughlin BE (1991) Does carbon monoxide have a physiological function? Trends Pharmacol Sci 12:185-188.

Matsuoka I, Giuili G, Poyard M, Stengel D, Parma J, Guellaen G, Hanoune J (1992) Localization of adenylyl and guanylyl cyclase in rat brain by in situ hybridization: comparison with calmodulin mRNA distribution. J Neurosci 12:3350-3360.

Montague PR, Gancayco CD, Winn MJ, Marchase RB, Friedlander MJ (1994) Role of NO production in NMDA receptor-mediated neurotransmitter release in cerebral cortex. Science 263:973-977.

Moore PK, Babbedge RC, Wallace P, Gaffen ZA, Hart SL (1993) 7-Nitro indazole, an inhibitor of nitric oxide synthase, exhibits antinociceptive activity in the mouse without increasing blood pressure. $\mathrm{Br}$ J Pharmacol 108:296-297.

Morley D, Keefer LK (1993) Nitric oxide/nucleotide complexes: a unique class of nitric oxide-based vasodilators. J Cardiovasc Pharmacol 22:S3-S9.

Motulsky HJ, Ransnas LA (1987) Fitting curves to data using nonlinear regression: a practical and nonmathematical review. FASEB J 1:365-374.

Murphy ME, Noack E (1994) Nitric oxide assay using hemoglobin method. Methods Enzymol 233:240-250.

Nicholson CD, Challiss RA, Shahid M (1991) Differential modulation of tissue function and therapeutic potential of selective inhibitors of cyclic nucleotide phosphodiesterase isoenzymes. Trends Pharmacol Sci $12: 19-27$.

Niroomand F, Mulsch A, Bohme E (1991) Thiol-independent stimulation of soluble guanylate cyclase by NO-containing compounds. Biochem Pharmacol 41:1777-1779. 
Palmer RM, Ashton DS, Moncada S (1988) Vascular endothelial cells synthesize nitric oxide from $L$ arginine. Nature 333:664-666.

Paupardin-Tritsch D, Hammond C, Gerschenfeld HM, Nairn AC, Greengard P (1986) cGMP-dependent protein kinase enhances $\mathrm{Ca}^{2+}$ current and potentiates the serotonin-induced $\mathrm{Ca}^{2+}$ current increase in snail neurones. Nature 323:812-814.

Pape H-C, Mager R (1992) Nitric oxide controls oscillatory activity on thalamocortical neurons. Neuron 9:441-448.

Ramos KS, Lin H, McGrath JJ (1989) Modulation of cyclic guanosine monophosphate levels in cultured aortic smooth muscle cells by carbon monoxide. Biochem Pharmacol 38:1368-1370.

Rees DD, Palmer RM, Schulz R, Hodson HF, Moncada S (1990) Characterization of three inhibitors of endothelial nitric oxide synthase in vitro and in vivo. Br $\mathbf{J}$ Pharmacol 101:746-752.

Sawada M, Ichinose M, Hara N (1995) Nitric oxide induces an increased $\mathrm{Na}^{+}$conductance in identified neurons of Aplysia. Brain Res 670:248-256.

Snyder SH, Bredt DS (1991) Nitric oxide as a neuronal messenger. Trends Pharmacol Sci 12:125-128.

Southam E, Garthwaite J (1991) Comparative effects of some nitric oxide donors on cyclic GMP levels in rat cerebellar slices. Neurosci Lett 130:107-111.

Stevens CF, Wang Y (1993) Reversal of long-term potentiation by inhibitors of haem oxygenase. Nature 364:147-149.
Verma A, Hirsch DJ, Glatt CE, Ronnett GV, Snyder SH (1993) Carbon monoxide: a putative neural messenger. Science 259:381-384.

Vincent SR (1994) Nitric oxide: a radical neurotransmitter in the central nervous system. Prog Neurobiol 42:129-160.

Vincent SR, Kimura H (1992) Histochemical mapping of nitric oxide synthase in the rat brain. Neuroscience 46:755-784.

Wang YY, Aghajanian GK (1987) Excitation of locus coeruleus neurons by an adenosine $3^{\prime}, 5^{\prime}$-cyclic monophosphate-activated inward current: extracellular and intracellular studies in rat brain slices. Synapse $1: 481-487$.

Wang YY, Aghajanian GK (1990) Excitation of locus coeruleus neurons by vasoactive intestinal peptide: role of a cAMP and protein kinase $A$. J Neurosci 10:3335-3343.

Williams JT, North RA, Shefner A, Nishi S, Egan TM (1984) Membrane properties of rat locus coeruleus neurones. Neuroscience 13:137-156.

Xu ZQ, Pieribone VA, Zhang X, Grillner S, Hökfelt T (1994) A functional rolc for nitric oxide in locus coeruleus: immunohistochenical and electrophysiological studies. Exp Brain Res 98:75-83.

Zhuo M, Small SA, Kandel ER, Hawkins RD (1993) Nitric oxide and carbon monoxide produce activity-dependent long-term synaptic enhancement in hippocampus. Science 260:1946-1950. 